http://dx.doi.org/10.18778/1508-1117.22.07

Daniel E. May

\title{
THE DEVELOPMENT AND USE OF CHARACTERISATION-BASED APPROACHES TO MANAGE HISTORIC LANDSCAPES
}

\begin{abstract}
The anthropogenic effect on the landscape is a well known phenomenon. This effect not only can be identified from archaeological remains, but also from old and modern maps showing changes in the landscape character in terms of historical attributes and remains. In order to study and manage the historical dimension of these changes, characterisation-based approaches have been developed. This article describes the main characteristics and principles of these approaches and their possible evolution in the future. The article also shows some applications that have been made in England with the purpose of illustrating the potential of characterisation-based approaches to manage historic landscapes in other countries.
\end{abstract}

Key words: historic landscape, characterisation-based approaches, historic landscape management.

\section{Characterisation-based approaches}

The historical-cultural dimension of the landscape has been considered by a number of researchers over a long period. However, it was not until 1992 that the UNESCO World Heritage Convention became the first international legal instrument to protect "cultural landscapes". This concept is defined by P. Fowler (2003) as a landscape that is "fashioned from a natural landscape by a culture group. Culture is the agent, the natural area the medium, the cultural landscape the result" (p. 17). The inclusion of cultural landscape on the UNESCO World Heritage list encouraged countries to enhance conservation and protection measures. In response to this development, the research on cultural landscape in Europe has been focussed on cultural landscape conservation and the analysis of landscape change (Martínez et al. 2010). For example, in Western Europe protection and conservation of cultural landscapes have been linked to the conservation of biodiversity and this has lead to a number investigation aimed to explore the relationship between biodiversity and cultural landscapes (Antrop 2004). In 
Central and Eastern Europe researchers have focussed on the implications of spacial and temporal diversity of landscapes on cultural landscape management and ways in which the harmony between the preservation of natural and cultural heritage may be restored by keeping people in place (Palang et al. 2006). Attention has also been placed on the relationship between cultural landscapes and landscape patterns and landforms (Wrbka et al. 2004).

In the UK, cultural aspects of landscape preservation have been studied from another perspective referred to as historic landscape. This concept is linked to concept of landscape defined by the European Landscape Convention as "an area, as perceived by people, whose character is the result of the action and interaction of natural and/or human factors" (Natural England 2009a, p. 1). According to this definition, the landscape is characterised by two dimensions, one related to a natural factors and another related to human factors. Historic landscape refers to the human or historic dimension of the landscape (Natural England, 2009b, p. 9). That is, it refers to the distinctive historic dimension of today's environment within a given area (Clark et al. 2004). Historic landscape is also defined by G. Fairclough et al. (2002) as the "physical remains and other historical attributes of the present landscape as indicators of how that landscape's character has developed over time through the interaction of people with their environment" (p. 69). The development of the historic landscape approach and its relationship with the idea of landscape characterisation is described as follows.

According to L. Macinnes (2004, p. 155) and S. Turner (2006, p. 389), lack of adequate protection of historic landscapes in England continued until the early 1990s. However, the idea that the totality of landscape character and change needs to be dealt with has surfaced since the 1970s (Roberts 1979, p. 157; Lake 2007, p. 29). As a result, a number of characterisation-based approaches have been proposed since the second half of the 1980s (Swanwick 2004, p. 111; Lake 2007, p. 29).

The first formal approach dealing with the issue of landscape characterisation was introduced in the mid-1980s and is referred to as Landscape Assessment (LA) (Swanwick 2004, p. 110). While LA was not normally used in assisting heritage conservation (Fairclough et al. 2002, p. 69), it is considered a building block for further developments that have been employed for this purpose. One of them is the Landscape Character Assessment (LCA) which is a form of LA that puts the emphasis on landscape character (Swanwick 2004, p. 111). The concept of characterisation and related terms that are considered by this approach are summarised in Fig. 1.

The idea behind the LCA is to identify patterns of elements in the landscape in order to classify and describe areas of either similar or different character. This approach is clearly different from the traditional focus on conserving isolated monuments and small areas. Indeed, this change in focus is evidence of the fact that the way in which historic management was carried out was starting to face an important change. 
Character: A distinct, recognisable and consistent pattern of elements in the landscape that makes one landscape different from another, rather than better or worse.

Characteristics: Elements, or combination of elements, which make a particular contribution to distinctive character.

Elements: Individual components which make up the landscape, such as trees and hedges.

Features: Particular prominent or eye-catching, like tree clumps, church towers, or wooded skylines.

Characterisation: The process of identifying areas of similar character, classifying and mapping them and describing their character.

Fig. 1. Words related to landscape character

Source: C. Swanwick (2002, p. 8)

The LCA is still being used by a number of researchers and policymakers (see for example James and Gittins 2007). However, it has been criticised because it oversimplifies the complexity of the ways in which the landscape is impacted by humans and fails to account for the historical dimension of the landscape (Macinnes 2004, p. 156). In recognising these problems, other characterisation-based approaches were developed in the 1990s. In general terms, these approaches have incorporated some principles and ideas that have been debated since the 1970s and that are currently considered as desirable for historic management, namely: time-depth; change; multidisciplinary approach; value-neutral methodologies; and sense of place. They are described as follows.

Time-depth refers to the historical dimension of the landscape and has the potential to inform about historic changes such as sites' development over time and historical development patterns (English Heritage and Homes Communities Agency 2009, p. 7). Given the key role of time-depth in providing this information, it is argued both that time-depth is the most important characteristic of landscape, and that archaeology is the most suitable discipline for this characterisation (Clark et al. 2004, p. 6; Lake 2007, p. 33).

The idea of change refers to the changes in landscape's character caused by the interaction between human actions and the environment over long periods of time (Fairclough et al. 2002, p. 69).

Regarding multidisciplinary approach, it is argued that the landscape is in itself an integrating concept. This is why the academic community has recognised that the study of historic landscapes requires multi-disciplinary and holistic approaches (Macinnes and Wickham-Jones 1992; Fairclough 2004; Turner 2007).

A potential problem that may arise when working with multidisciplinary approaches is that individuals might assign higher value to characteristics that are linked to their respective disciplines. The idea of value-neutral methodologies was introduced with the objective of preventing different individuals from placing greater emphasis on aspects of the landscape that are considered more important by them (Herring 2007, p. 17). 
Finally, the idea of sense of place refers to the unique historical trajectory in the landscape that provides identity. This identity contributes to the survival of the past in the present landscape and to maintaining a sense of continuity and belonging (Alfrey 2007, p. 90).

The majority of the existing characterisation-based approaches have adopted the ideas and thoughts described above. According to English Heritage (2012a, p. 3) these approaches are: (i) Historic Landscape Characterisation (HLC); Historic Seascape Characterisation (HSC); Urban Historic Characterisation (UHC); Historic Area Assessment (HAA); Conservation Area Appraisal (CAA); and Conservation Management Plan (CMP). The main characteristics of these approaches are summarised in Tab. 1.

Table 1

Characteristic of existing characterisation-based approaches

\begin{tabular}{|c|c|c|c|c|c|c|}
\hline \multirow{2}{*}{ Characteristic } & \multicolumn{6}{|c|}{ Existing characterisation-based approaches } \\
\hline & HLC & HSC & UHC & HAA & CAA & CMP \\
\hline $\begin{array}{l}\text { Main } \\
\text { focus }\end{array}$ & $\begin{array}{l}\text { Map-based } \\
\text { framework } \\
\text { used to gain } \\
\text { an under- } \\
\text { standing of } \\
\text { the whole } \\
\text { landscape } \\
\text { highlighting } \\
\text { historical } \\
\text { land use }\end{array}$ & $\begin{array}{c}\text { Maps an } \\
\text { understanding } \\
\text { of the cultural } \\
\text { processes } \\
\text { shaping the } \\
\text { present } \\
\text { landscape in } \\
\text { coastal and } \\
\text { marine areas }\end{array}$ & $\begin{array}{l}\text { Approach } \\
\text { used to } \\
\text { assess small } \\
\text { towns } \\
\text { through an } \\
\text { analysis of } \\
\text { existing } \\
\text { archaeolo- } \\
\text { gical, } \\
\text { topograph- } \\
\text { ical and } \\
\text { historic } \\
\text { sources }\end{array}$ & \begin{tabular}{|} 
Method \\
focussed on \\
the historic \\
built land- \\
scape and \\
used to \\
understand \\
in a short \\
period of \\
time herit- \\
age interest \\
of small/ \\
medium \\
areas
\end{tabular} & $\begin{array}{c}\text { Addresses } \\
\text { the needs of } \\
\text { England's } \\
\text { designated } \\
\text { conservation } \\
\text { areas. It } \\
\text { incorporates } \\
\text { some form } \\
\text { of HAA }\end{array}$ & $\begin{array}{c}\text { Tool for } \\
\text { understand- } \\
\text { ing, planning } \\
\text { and man- } \\
\text { aging large } \\
\text { sites such as } \\
\text { historic parks } \\
\text { and gardens }\end{array}$ \\
\hline $\begin{array}{l}\text { Coverage } \\
\text { and } \\
\text { landscape } \\
\text { type }\end{array}$ & $\begin{array}{l}\text { High level } \\
\text { covering } \\
\text { whole } \\
\text { landscapes } \\
\text { (e.g. } \\
\text { Counties) }\end{array}$ & $\begin{array}{c}\text { Coast and } \\
\text { marine areas }\end{array}$ & Small towns & \begin{tabular}{|} 
Small/ \\
medium size \\
towns, \\
suburbs, \\
villages
\end{tabular} & $\begin{array}{c}\text { Designated } \\
\text { conservation } \\
\text { areas }\end{array}$ & $\begin{array}{c}\text { Management } \\
\text { plans are set } \\
\text { out for each } \\
\text { distinct } \\
\text { character } \\
\text { area of the } \\
\text { site defined } \\
\text { by an } \\
\text { appraisal si- } \\
\text { milar to HAA }\end{array}$ \\
\hline
\end{tabular}

Source: English Heritage (2012a, 2012b, 2013).

According to this table, the main differences between these approaches are their coverage and their focus. However, they share in common the ideas described above. In order to illustrate this fact, a brief description of the commonly used HLC approach is given as follows.

The HLC is defined as "the process of representing and interpreting predominant historic character across the whole of a region" (Herring 2007, p. 15). Its 
aims are to map the character and time-depth of the whole landscape, to manage change rather that protection, and to serve as a platform for understanding change by means of landscape characterisation (Lake 2007, p. 28). This approach is aligned with the principles of accessibility, inclusivity (i.e. involving a wide range of communities) and flexibility underpinned by the European Landscape Convention (Finch 2007, p. 50; Herring 2007, p. 16). The HLC is based on GIS to map the landscape and used to create generalisations in order to understand patterns in the landscape in broader scales (Turner 2007, p. 44).

The HLC methodology has already been used with the purpose of carry out landscape management (e.g. advising agri-environment schemes); landscape character assessment and strategies (e.g. to inform landscape strategies at a country and district level); spatial planning (to inform new planning policies and advice on planning applications); and partnership, learning and outreach (e.g. support other aspects of environmental management and to inform research in both local authorities and universities helping to raise awareness of the historic landscape). Some examples of how the HLC methodology has been applied in practice are presented as follows.

The Buckinghamshire region (county) of the UK has an impressive historic landscape that reflects the influence of prehistoric farmers, medieval lords and peasants, the gentry's garden designers and Victorian surveyors. In order to map these changes, a historic landscape characterisation project was developed in this county with the purpose of generating the information that is needed to carry out management and planning initiatives in the future (Buckinghamshire County Council 2006). As a result of this project, a number of maps that characterise the distinctive, historic dimension of today's landscape were obtained. The project started with the landscape as observed on modern maps and aerial photographs, and each piece of land was assigned a broad landscape group (e.g. enclosures, woodland, settlements etc.). For each of these groups, a number of more detailed historic landscape types were defined (e.g. pre $18^{\text {th }}$ Century co-axial enclosure, parliamentary enclosure etc.). Old maps of the $19^{\text {th }}$ century were also considered in the project. Morphology, seen as an archaeological way of identifying shape and patterns of fields and other patterns was also recorded. The aim of recording morphology was to interpret the origin, development and history of fields and settlements. In this context, regular shaped fields were associated with surveyed of planned countryside such as parliamentary enclosure. In contrast, more irregular fields were associated with much older landscapes. Using this approach, a list of Buckinghamshire historic landscape types was defined and allocated on modern map and aerial photographs as well as earlier maps in order to detect changes. The following figures shows how the historic landscape in South Health, Great Missenden, Buckinghamshire, has changed since 1811. The GIS-based maps using in this figure plays a key role in characterising this change and is considered as an important tool for planning and managing the landscape. 


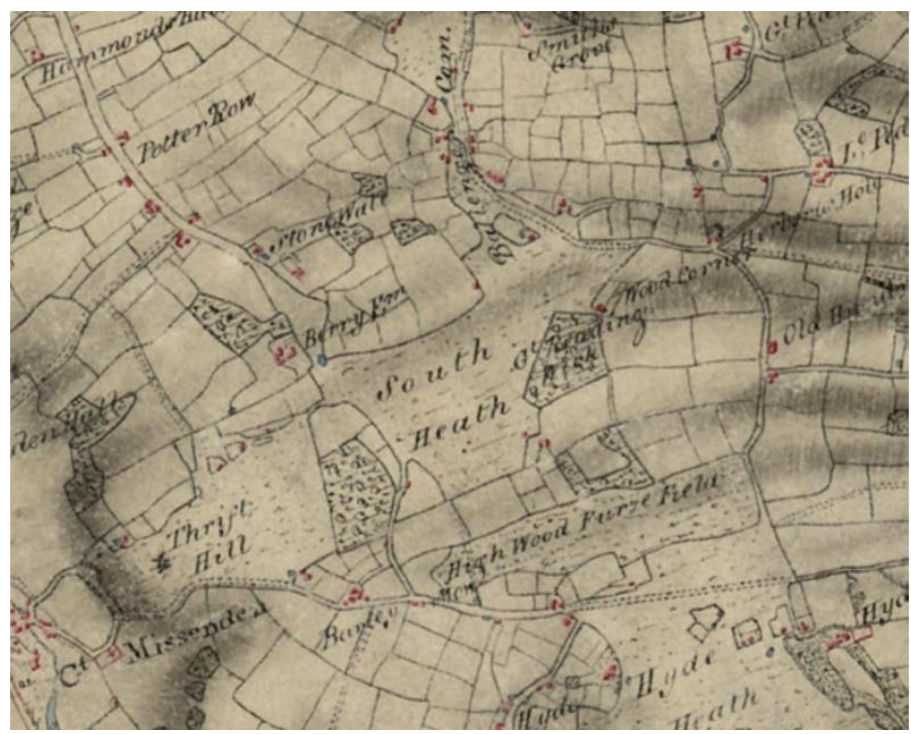

Fig. 2. Map of South Health, Great Missenden, Buckinghamshire in 1811

(Ordanance Survey 2', Suveyoris Drawings 1811 (c) British Library

Source: Buckinghamshire County Council (2006)

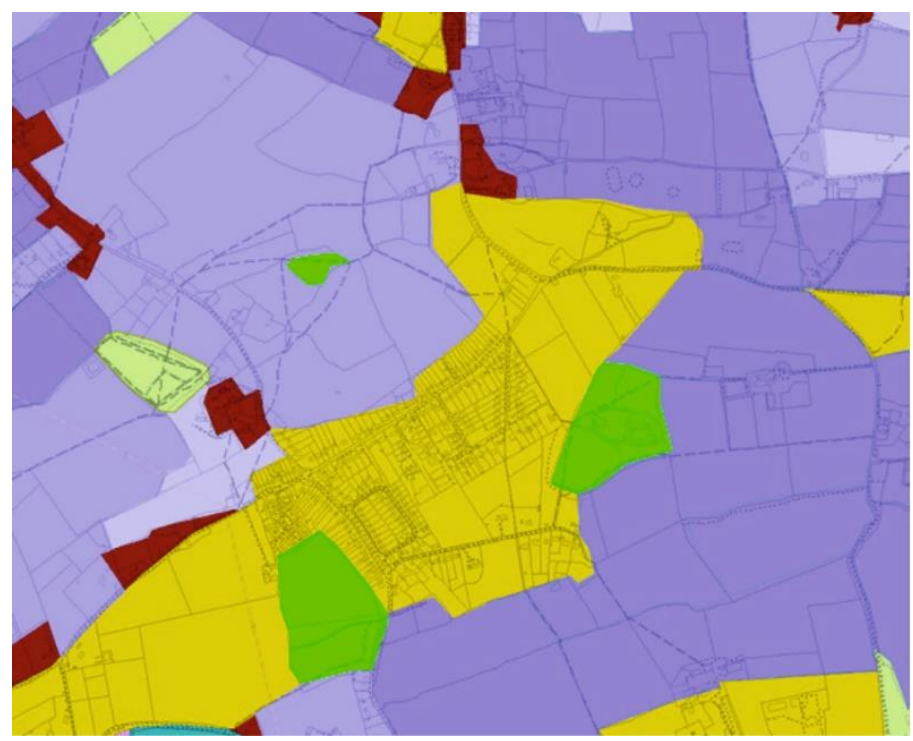

Fig. 3. HLC map showing the interpretation of landscape at the beginning of the $19^{\text {th }}$ century based on the map presented in Fig. 2. The area is dominated by a heath (mustard yellow), which was eventually enclosed by the Act of parliament. Although the surrounding landscape of enclosures and woodland remains relatively unchanged through two hundred years Source: Buckinghamshire County Council (2006) 


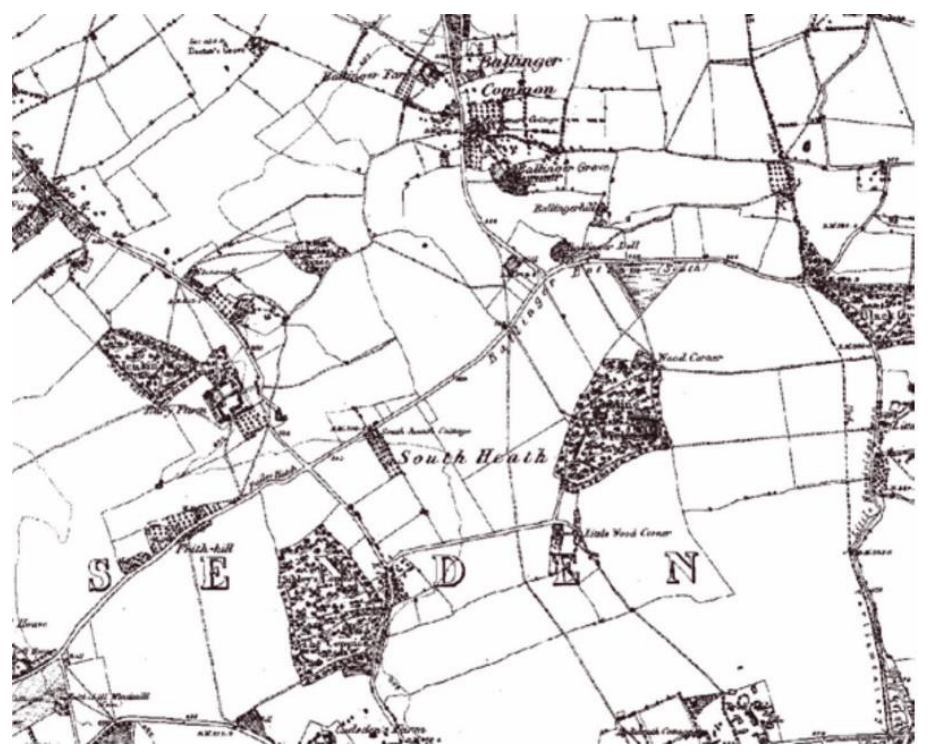

Fig. 4. Map of South Health, Great Missenden, Buckinghamshire in 1878

(Ordanance Survey $1^{\text {st }}$ Edition 6" map 1878 (c) Sitescope Limited Source: Buckinghamshire County Council (2006)

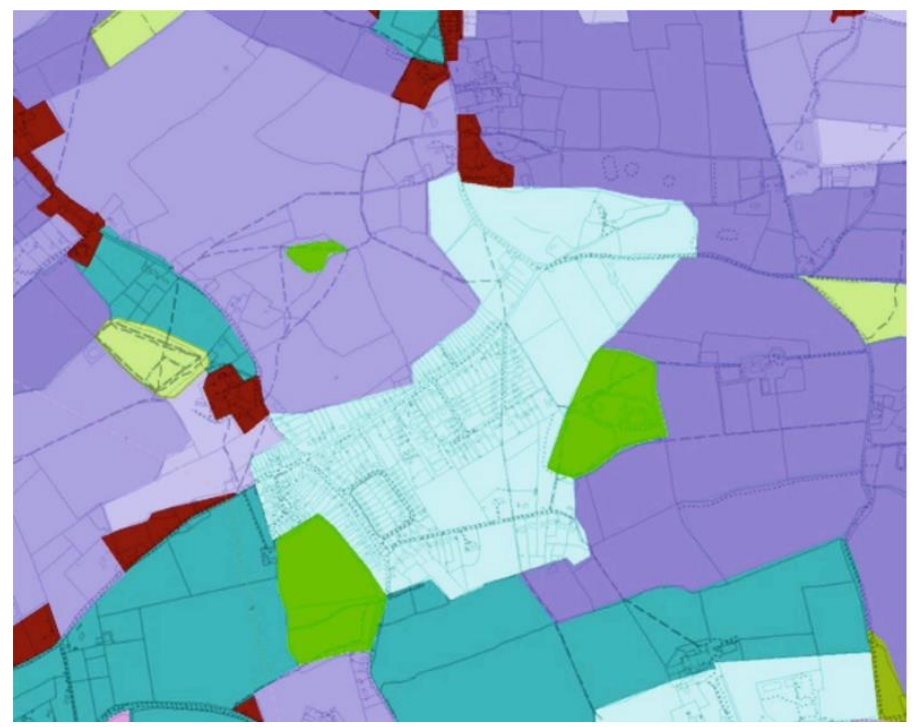

Fig. 5. HLC map showing the late $19^{\text {th }}$ century landscape based on the map presented in Fig. 4. The regular fields (pale blue) were created by a parliamentary enclosure act in the $19^{\text {th }}$ century are free of modern settlement, although historic settlement (farmsteads) are shown as (brown). The ancient fields (purple) are of the same extent and woodland still remains largely unchanged and unaltered

Source: Buckinghamshire County Council (2006) 


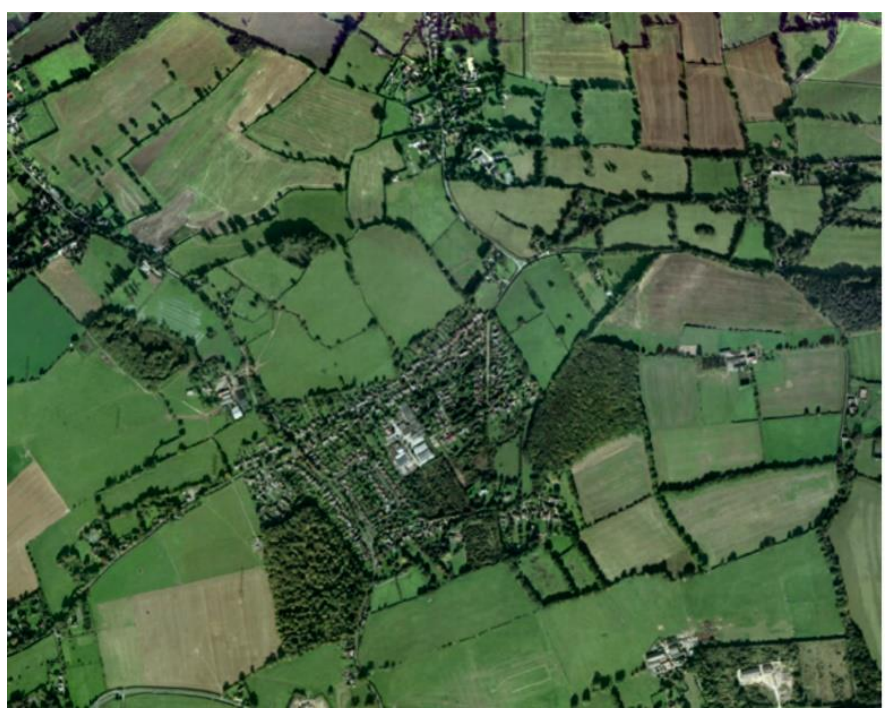

Fig. 6. Aerial photograph of South Health, Great Missenden, Buckinghamshire in 2003 (Aerial Photograph 2003 (c) UK Persoectives Source: Buckinghamshire County Council (2006)

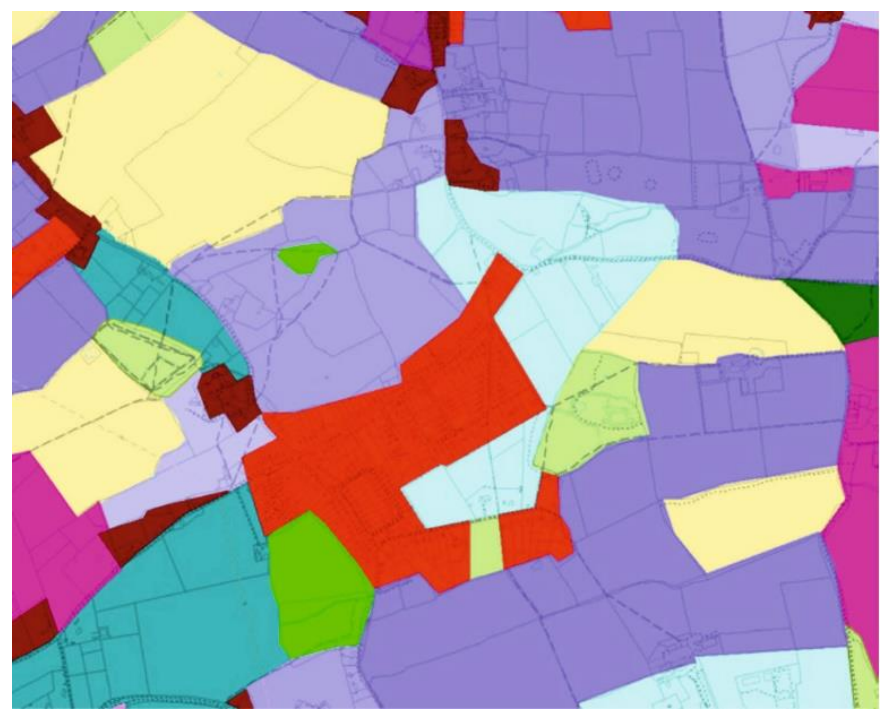

Fig. 7. HLC map highlighting the influence of the $20^{\text {th }}$ century on the landscape based on the aerial photographs presented in Fig. 6. It shows how modern settlement (red) has encroached upon the regular shaped fields (pale blue). While some enclosures show some degree of boundary loss (yellow), probably as a result of modern farming methods. The surrounding landscape is made up of older irregular enclosures and coaxial enclosures (purple) and ancient woodland (green)

Source: Buckinghamshire County Council (2006) 
Another example is the application of HLC in the town of Clitheroe located in the County of Lancashire, UK. A planting scheme was proposed for an area situated near this town. This comprised arable open fields that has been enclosed in the late medieval period and retained extensive remains of the field system of that period of time. As a consequence, the proposal to plant trees across the field system was unsympathetic to the historic landscape character and the scheme was modified in order to maintain the historic landscape character as shown in Fig. 8.

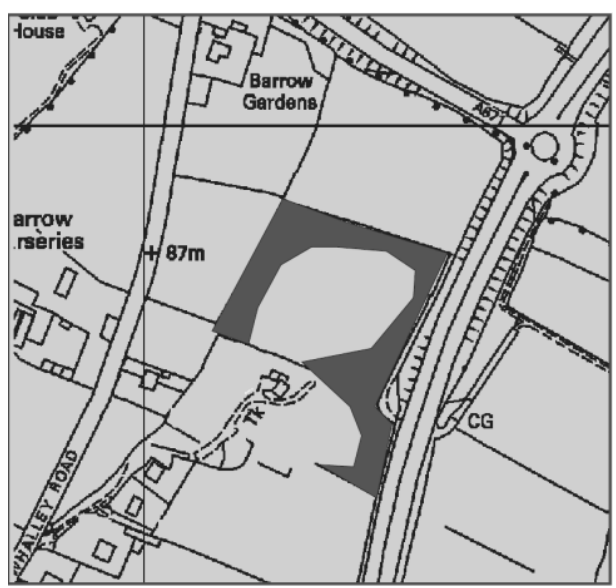

Original planting scheme

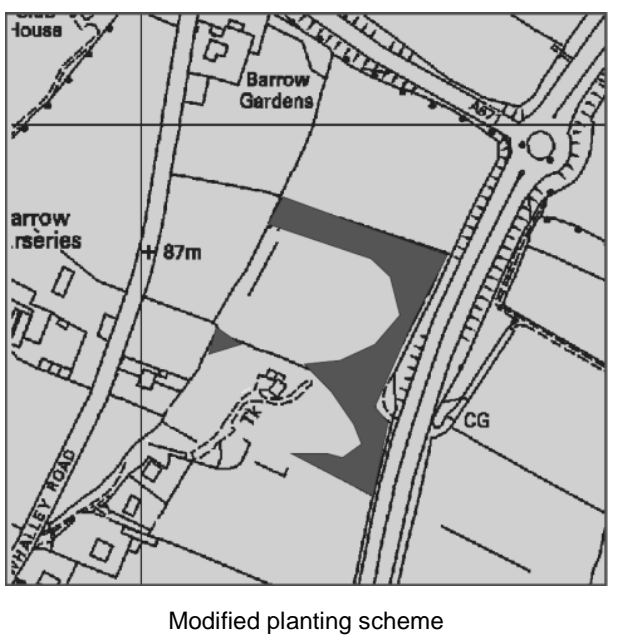

Fig. 8. Changing planting scheme in order to preserve the historic landscape character of Clitheroe, Lancashire

Source: J. Clark et al. (2004)

A final example is the application of the HLC methodology to provide information for the local authority about the impact of building between 3200 and 5000 houses in a site located west of Stevenage in the county of Hertfordshire, UK. The HLC output (see Fig. 9) revealed that the historic landscape of the area retains much of its older characteristic and integrity, and this information was considered by the authority when deciding about building the new houses.

\section{Ways in which characterisation-based approaches are affecting the management of historic landscapes}

The previous section detailed how current characterisation-based approaches have incorporated some ideas and thoughts that have been debated over a long period of time, namely: time-depth; change; multidisciplinary approach; value-neutral methodologies; and sense of place. As discussed in this section, the introduction of these ideas has strongly affected the means by which historic landscape management is carried out. The main effects are on the nature of the historic unit to be managed; management focus; and interpretation. 


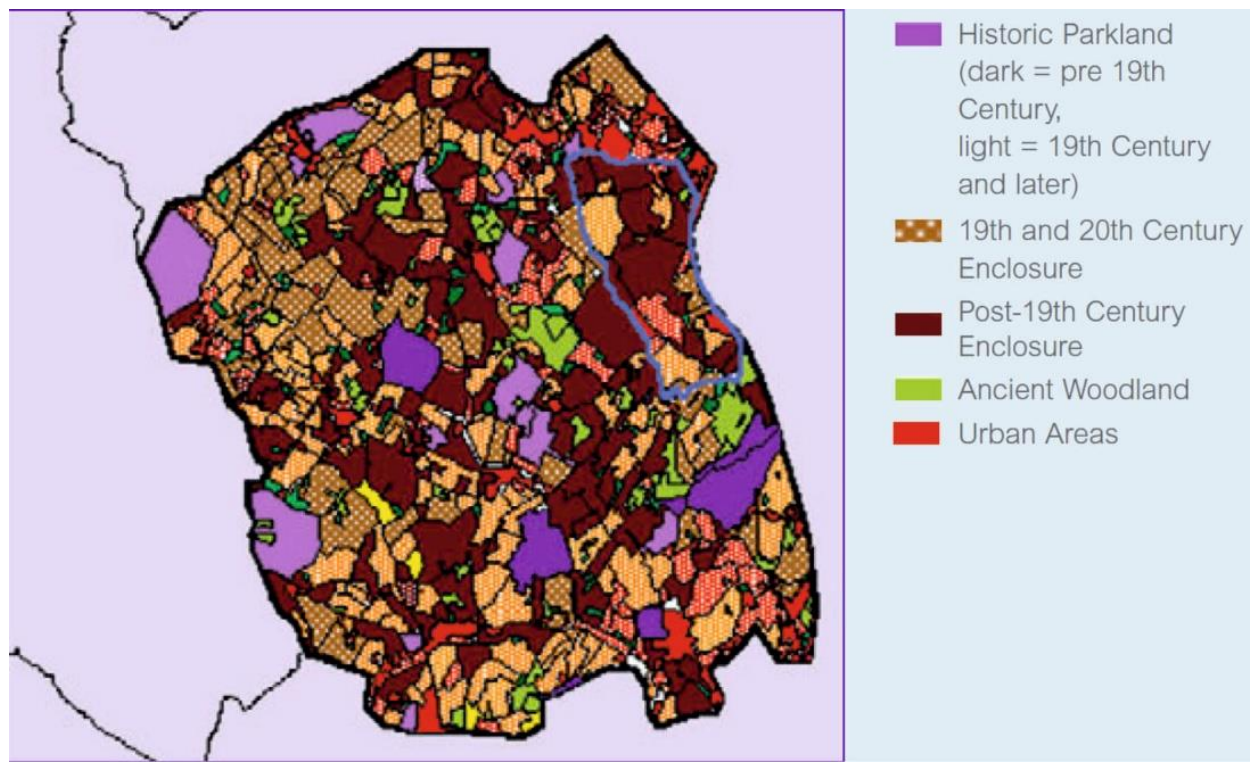

Fig. 9. HCL output developed to characterise an historic landscape in Hertfordshire

Source: J. Clark et al. (2004)

The nature of the historic unit to be managed has been influenced by the idea of time-depth. That is, the emphasis of historic management has changed from a selective conservation approach of single monuments and small areas to a whole landscape perspective because historical patterns and historic dimension (i.e. time-depth) can be better understood when considering large landscape scales (Lake 2007, p. 33). In this new perspective, historic characterisation is seen a fundamental exercise as it provides the basis for interpreting and understanding historic landscapes before the implementation of planning, conserving and management initiatives (English Heritage and Homes and Communities Agency 2009, p. 6).

Regarding management focus, this focus has been influenced by the idea of change. That is, the historic landscape management approach that has been implemented in England since the 1990s is flexible and holistic allowing change rather than keeping the landscape fixed ${ }^{1}$ (Fairclough 2004, unpaged). This is formally pointed out by J. Lake (2007) who argues that "the challenge is to inform and even facilitate sustainable change based on understanding of the inter-related patterns of the landscape, settlement and architecture in response to a widespread demand to capitalise on local character and distinctiveness" (p. 34). In this context the existing characterisation-based approaches that have incorporated the idea of

${ }^{1}$ Some researchers call this form of historic management the management of change (Belcher 2008, p. 27; Williamson 2007, p. 68-69). 
change (see the previous section) serve as platforms for understanding change at subsequent stages by means of landscape characterisation in order to evaluate and assess the sensitivity of proposed changes (Fairclough 2004, unpaged; Herring 2007, p. 18; Turner 2007, p. 46).

Finally, regarding interpretation, this term is associated with the ideas of a multidisciplinary approach; value-neutral methodologies; and sense of place described in the previous section. In terms of multidisciplinary approach and value-neutral methodologies, historic landscape management in England has adopted a flexible approach in which the output obtained from a characterisation study is used in posterior stages as an input for further interpretation made by a multidisciplinary team. The work carried out by this team uses maps and GIS to plot gathered information on geology, landform, soils, vegetation, trees/woodland, land use, enclosure/field patterns, and settlement patterns. This information is then used to make decisions regarding, for example, agri-environment scheme targets, woodland expansion, and historic landscape conservation, among others (Swanwick 2002, p. 3, 18, 21 and 22). Interpretation is supposed to be carried out in a democratic fashion in order to avoid biases in favour of determined disciplines. This is a reflection of the idea of value-neutral methodologies described above. However, this idea does not mean that the landscape is itself value-neutral, but that any interpretation has to reflect the value agreed by a multidisciplinary team or by those who will work with the results ${ }^{2}$ (English Heritage 1997, p. 5). This flexibility in terms of interpretation is demonstrated in the diversity of applications that have been carried out with the assistance of characterisation-based approaches. Examples of these applications are local planning, large-scale planning, community engagement, development management, conservation areas, and green infrastructure (English Heritage 2012a, p. 25). Interpretation is also related to the idea of sense of place because it is a way of recognising significance and a sense of place defined by communities along with any value offered by experts (Finch 2007, p. 51).

\section{Current criticisms}

A number of criticisms have been raised regarding existing characterisation-based approaches that might affect historic landscape management in the future. Some of them are described as follows.

It is argued that these approaches do not capture the complexity of the landscape and are used for political programmes seeking regional planning and development of an undemocratic nature (Austin 2007, p. 94; Williamson, 2007, p. 64). It is also argued that different counties have adopted their own

\footnotetext{
${ }^{2}$ In this respect, the English Heritage promotes four broad sets of values set out in Conservation Principles through which a site or place should be interpreted, namely: evidential, historical, communal and aesthetic (English Heritage 2012c, p. 9).
} 
methodologies developed by people with different background making it difficult to compare landscapes across counties. Another criticism is that characterisation-based approaches map field or blocks but not linear features within. As a consequence, two blocks considered as different may have much in common when considering their linear features. A related criticism is that landscape characterisation is misleading because characteristics features are plotted in a plan as if seen from above. But in reality people experience the landscape from the ground (Williamson 2007, p. 65). Finally, it is argued that characterisation-based approaches are supposed to be value-neutral methodologies for mapping material forms in the landscape. However, these approaches do not recognise subjective perspectives of landscapes constructed through perception rather than materiality (Finch 2007, p. 51). In line with this view, G. Fairclough (2004, unpaged) argues that historic landscape management should also include managing perceptions by means of knowledge.

\section{Conclusions}

To conclude, it is argued that a possible evolution of historic landscape management in England will include methodological improvements of existing characterisation-based approaches rather than changes to the ideas and principles embedded within them. This prediction is based on the current criticisms described in the previous section. That is, most of these criticisms are focussed solely on methodological aspects of characterisation-based models. Consequently, it is anticipated that a possible evolution of historic landscape management will include methodological improvements of existing approaches and management practices. In particular, the following is anticipated: more emphasis in homogenising methodologies in order to facilitate the comparison between landscapes across counties; extensions to existing methodologies in order to include linear features into the mapping process; an increase in the number of field visits during characterisation studies with the purpose of reducing to some extent the chance of making misleading characterisations; and the development of ways to manage perceptions in order to introduce subjective perspectives into historic landscape management.

\section{BIBLIOGRAPHY}

Alfrey L., 2007, Contexts for Historic Landscape Characterisation in Wales, „Landscapes", 8(2), s. 84-91.

Antrop M., 2004, Landscape change and the urbanization process in Europe, ,Landscape Urban Plan", 67(1-4), s. 9-26.

Austin D., 2007, Character or Caricature? Concluding Discussion, „Landscapes”, 8(2), s. $92-105$. 
Belcher J., 2008, Historic landscape characterisation: an exploration of the method and means of understanding enclosure, „Landscapes”, 2, s. 26-44.

Buckinghamshire County Council, 2006, Buckinghamshire \& Milton Keynes: Historic Landscape Characterisation, County Archaeological Service.

Clark J., Darlington J., Fairclough G., 2004, Using Historic Landscape Characterisation: English Heritage's Review of HLC Applications 2002-03, English Heritage and Lancashire County Council, London and Preston.

English Heritage, 1997, Sustaining the historic environment: new perspectives on the future, English Heritage, London.

English Heritage, 2012a, Understanding Place: Character and Context in Local Planning, English Heritage.

English Heritage, 2012b, Understanding Place: Historic Area Assessment, Principles and Practice, English Heritage.

English Heritage, 2012c, Understanding Place: Historic Area Assessment in a Planned and Development Context, English Heritage.

English Heritage, 2013, Historic Seascape Character, http://www.english-heritage.org. $\mathrm{uk} / \mathrm{professional/research/landscapes-and-areas/characterisation/historic-seascape-cha-}$ racter/.

English Heritage and Homes Communities Agency, 2009, Capitalising on the Inherited Landscape, English Heritage and Homes Communities Agency.

Fairclough G., Lambrick, G., Hopkins, D., 2002, Historic Landscape Characterisation in England and a Hampshire Case Study, [w:] Fairclough G., Rippon S. (red.), Europe's Cultural Landscape: Archaeologists and the Management of Change, Europae Archaeologiae Consilium, s. 69-83.

Fairclough, G., 2004, History and time: managing landscape and perceptions, From Knowledge of Landscapes to Landscaping Action, Bordeaux, France.

Finch J., 2007, Wider Famed Countries: Historic Landscape Characterisation in the Midland Shires, „Landscapes”, 8(2), s. 50-63.

Fowler P., 2003, World Heritage Cultural Landscapes, 1992-2002, UNESCO World Heritage Paper 6, Paris.

Herring P., 2007, Historic Landscape Characterisation in an Ever-Changing Cornwall, „Landscapes”, 8(2), s. 15-27.

James P., Gittins J.W., 2007, Local Landscape Character Assessment: An Evaluation of Community-led Schemes in Cheshire, „Landscape Research”, 32(4), s. 423-442.

Lake J., 2007, The English Pays: Approaches to Understanding and Characterising Landscapes and Places, „Landscapes”, 8(2), s. 28-39.

Macinnes L., 2004, Historic Landscape Characterization, [w:] Bishop K., Phillips A. (red.), Countryside Planning: New Approaches to Management and Conservation, Earthcan, s. 155-169.

Macinnes L., Wickham-Jones C.R., 1992, Time-depth in the countryside: archaeology and the environment, [w:] Macinnes L., Wickham-Jones C.R. (red.), All Natural Things: Archaeology and the Green Debate, Oxbow Monograph, Oxford, s. 1-13.

Martínez S., Ramil P., Chuvieco E., 2010, Monitoring loss of biodiversity in cultural landscapes. New methodology based on satellite data, ,Landscape and Urban Planning”, 94, s. 127-140.

Natural England, 2009a, European Landscape Convention Guidance Part 1, http://publications.naturalengland.org.uk/publication/6361194094919680? category=31019. 
Natural England, 2009b, European Landscape Convention Guidance Part 2, http://publications.naturalengland.org.uk/publication/6361194094919680? category=31019.

Palang H., Printsmann A., Gyuro E.K., Urbanc M., Skowronek E., Woloszyn W., 2006, The forgotten rural landscapes of Central and Eastern Europe, „Landscape Ecology”, 21, s. 347-357.

Roberts B.K., 1979, Rural Settlements in Britain, Hutchinson, London.

Swanwick C., 2002, Landscape Character Assessment Guidance for England and Scottish, Countryside Agency and Natural Heritage, Cheltenham and Edinburg.

Swanwick C., 2004, The Assessment of Countryside and Landscape Character in England: An Overview, [w:] Bishop K., Phillips A. (red.), Countryside Planning: New Approaches to Management and Conservation, Earthcan, s. 109-124.

Turner S., 2006, Historic Landscape Characterisation: A Landscape Archaeology for Research, Management and Planning, ,Landscape Research”, 31(4), s. 385-398.

Turner S., 2007, Landscape Archaeology for the Past and Future: The Place of Historic Landscape Characterisation, „Landscapes”, 8(2), s. 40-49.

Williamson T., 2007, Historic Landscape Characterisation: Some Queries, „Landscapes", 8(2), s. 64-71.

Wrbka T., Erb K.H., Schulz N.B., Peterseil J., Hahn C., Haber H., 2004, Linking pattern and process in cultural landscapes. An empirical study based on spatially explicit indicators, „Land Use Policy”, 21, s. 289-306.

\section{ROZWÓJ I WYKORZYSTANIE METOD W OPARCIU O CHARAKTERYSTYKE KRAJOBRAZOWĄ W ZARZĄDZANIU HISTORYCZNYM KRAJOBRAZEM KULTUROWYM}

Zarys treści: Antropogeniczny wpływ na krajobraz jest powszechnie znanym zjawiskiem. Wpływ ten może zostać zidentyfikowany nie tylko dzięki archeologicznym znaleziskom, ale również dzięki archiwalnym i współczesnym mapom, pokazującym w krajobrazie elementy i pozostałości przeszłości. Aby poznać i zarządzać zmianami w krajobrazie, powstały metody oparte na charakterystyce krajobrazowej. Prezentowany artykuł opisuje główne cechy i prawidłowości takiego podejścia metodologicznego oraz potencjalne możliwości jego rozwoju w przyszłości. W pracy przedstawiono również brytyjskie propozycje zastosowania opisywanej metodologii do zarządzania krajobrazem historycznym w innych krajach.

Słowa kluczowe: historyczny krajobraz kulturowy, podejście oparte o charakterystykę, zarządzanie krajobrazem historycznym.

Dr Daniel E. May

Kellogg College University of Oxford, England 